\title{
Znaczenie wyroku Trybunału Sprawiedliwości UE z 20 marca 2018 r. w sprawie C-187/16 dla oceny zgodności rządowego projektu ustawy o dokumentach publicznych (druk 2153) z prawem UE ${ }^{1}$
}

\begin{abstract}
Significance of the judgment of the Court of Justice of the European Union in case C-187/16 for assessment of the governmental Bill on Public documents (Sejm's Paper no. 2153) in the aspect of conformity to the EU law (WAPM-735/18): The opinion presents the subject of the dispute and the judgment in the case C-187/16, the comparison of legal and factual situation related to that case with measures proposed in the governmental Bill as well as assessment on the significance of this judgment for further work on this Bill. The state of law being assessed in the case C-187/16 is comparable to measures included in the governmental Bill. The main difference is that Österreichische Staatsdruckerei is a private company, whereas the company mentioned in Article 17 of the bill shall be a company wholly owned by the State Treasury. Therefore, in the author's opinion it is possible to encompass production of given documents by the exemption provided in Article 12 para. 1 of the Directive 2014/24, but under additional conditions. If the Company is not considered an entity covered by this exemption, invoking the need to protect essential security interests of the state would require supplementing the grounds of the Bill by taking into account the position of the Court of Justice in the judgment C-187/16.
\end{abstract}

Keywords: public documents, governmental bill, public procurement, in-house

Słowa kluczowe: dokumenty publiczne, rządowy projekt ustawy, zamówienia publiczne, in-house

Opinia sporządzona 27 kwietnia 2018 r. na zlecenie przewodniczącego Komisji Administracji i Spraw Wewnętrznych; BAS-WAPM 735/18. 


\section{Przedmiot opinii}

Niniejsza opinia została sporządzona w odpowiedzi na pytanie o znaczenie wyroku Trybunału Sprawiedliwości UE (dalej: Trybunał lub TSUE) z 20 marca 2018 r. w sprawie C-187/16 (dalej: wyrok) ${ }^{2}$ dla oceny zgodności rządowego projektu ustawy o dokumentach publicznych z prawem UE. Opinia zawiera przedstawienie przedmiotu sporu i rozstrzygnięcia w sprawie C-187/16, porównanie sytuacji prawnej i faktycznej stanowiącej kanwę wyroku z rozwiązaniami proponowanymi w projekcie ustawy oraz ocenę znaczenia wyroku dla dalszych prac nad projektem.

\section{Postępowanie w sprawie C-187/16}

\section{Przepisy austriackie stanowiące przedmiot oceny w sprawie C-187/16}

Zgodnie z $\$ 1$ federalnej ustawy o reorganizacji sytuacji prawnej Österreichische Staatsdruckerei (dalej: ÖSD): ma ona za zadanie świadczyć na rzecz federalnych jednostek administracji usługi w zakresie wytwarzania produktów drukowanych, w przypadku których proces produkcji wymaga zachowania tajemnicy lub przestrzegania przepisów bezpieczeństwa (dalej: druk zabezpieczony). ÖSD jest spółką z ograniczoną odpowiedzialnością prawa prywatnego $(\mathrm{GmbH})$, której jedynym wspólnikiem jest Österreichische Staatsdruckerei Holding AG, przy czym akcje tej ostatniej są notowane na giełdzie i pozostają w posiadaniu osób prywatnych. Ustawa nie przewiduje żadnego specjalnego mechanizmu kontroli państwowej w odniesieniu do ÖSD, natomiast władze austriackie mają uprawnienia do kontroli określone w umowie zawartej z ÖSD (pkt 49 wyroku).

Zgodnie $\mathrm{z} \$ 2$ ust. 3 tej ustawy wytwarzanie druków zabezpieczonych może być powierzane przez organy federalne wyłącznie ÖSD, chyba że spółka ta nie jest w stanie z przyczyn faktycznych lub prawnych należycie wykonywać zadań po rozsądnych cenach lub jeżeli dany produkt jest zaoferowany organowi federalnemu przez stronę trzecią po niższej cenie, przy zachowaniu tych samych świadczeń i warunków umownych. Zgodnie z $\$ 6$ ust. 1 ustawy transakcje i działania odnoszące się do wytwarzania, przetwarzania i przechowywania druków zabezpieczonych podlegają kontroli ministra federalnego odpowiedzialnego za dany druk zabezpieczony. Ponadto, na mocy $\$ 6$ ust. 2 tej samej ustawy ÖSD podejmuje wszelkie niezbędne środki bezpieczeństwa w odniesieniu do wytwarzania, przetwarzania i przechowywania druków zabezpieczonych w celu zapobieżenia nadużyciom, a także zapewnia ministrowi federalnemu odpowiedzialnemu za

2 Wyrok TSUE (Wielka Izba) z 20 marca 2018 r. w sprawie C-187/16, Komisja Europejska v. Republika Austrii, ECLI:EU:C:2018:194. 
dany druk zabezpieczony dostęp do pomieszczeń gospodarczych i wgląd do danej dokumentacji handlowej w zakresie niezbędnym dla kontroli (ust. 3). Właściwe rozporządzenia austriackie określają warunki wytwarzania poszczególnych kategorii dokumentów. Wynika z nich, że - z zastrzeżeniem wyjątku wskazanego $w \$ 2$ ust. 3 tej ustawy - wytwarzanie paszportów, dokumentów pobytowych, praw jazdy w formacie karty bankomatowej, dowodów rejestracyjnych w formacie karty bankomatowej oraz legitymacji pirotechnika może być zlecane wyłącznie ÖSD ${ }^{3}$.

\section{Wniesienie skargi do TSUE oraz argumenty stron}

Zgodność powyższych przepisów z prawem UE została poddana analizie przez TSUE na skutek skargi wniesionej 4 kwietnia 2016 r. przez Komisję Europejską (dalej: KE) w trybie art. 258 Traktatu o funkcjonowaniu Unii Europejskiej (dalej: TFUE) (sprawa C-187/16, Komisja Europejska v. Austria). Wniesienie skargi było poprzedzone przeprowadzeniem postępowania administracyjnego w trybie art. 258 TFUE, wszczętego przez KE pismem z 6 kwietnia 2011 r. („wezwanie do usunięcia uchybienia”). Powyższe daty są o tyle istotne, że data implementacji dyrektywy 2014/244 została wyznaczona na 18 kwietnia 2016 r. i tego samego dnia traciła moc obowiązującą dyrektywa 2004/185. Wyjaśnia to, dlaczego Komisja Europejska nie mogła zarzucić Austrii naruszenia dyrektywy 2014/24.

W ocenie Austrii, zgodnie z art. 4 ust. 2 dyrektywy 92/50' i art. 14 dyrektywy 2004/18 rozważane zamówienia nie są objęte zakresem stosowania tych dyrektyw. Państwo to uważa, że jest uprawnione do ochrony swoich podstawowych interesów bezpieczeństwa i może stosować do realizacji omawianych zamówień szczególne środki bezpieczeństwa, zgodnie z przepisami ustawowymi i administracyjnymi obowiązującymi w Austrii. To do państw członkowskich należy bowiem określenie podstawowych interesów swojego bezpieczeństwa i ustalenie,

3 Należy zaznaczyć, że pierwotnie przedmiotem postępowania prowadzonego przez Komisję przeciwko Austrii były analogiczne wymogi dotyczące wytwarzania kart motorowerowych, dowodów rejestracyjnych w wersji papierowej, patentów żeglarskich, formularzy dokumentów bezpieczeństwa i winiet dla substancji uzależniających. Przepisy te zostały jednak zmienione przez Austrię (wykreślenie wymienionych dokumentów lub objęcie ich procedurą przetargową), w związku z czym Komisja wycofała zarzuty w tym zakresie (pkt 35 i 40 wyroku).

4 Dyrektywa Parlamentu Europejskiego i Rady 2014/24/UE z 26 lutego 2014 r. w sprawie zamówień publicznych, uchylająca dyrektywę 2004/18/WE, Dz.Urz. UE L 94 z 28 marca 2014 r., s. 65.

5 Dyrektywa 2004/18/WE Parlamentu Europejskiego i Rady z 31 marca 2004 r. w sprawie koordynacji procedur udzielania zamówień publicznych na roboty budowlane, dostawy i usługi, Dz.Urz. UE L 134 z 30 kwietnia 2004 r., s. 114.

6 Dyrektywa Rady 92/50/EWG z 18 czerwca 1992 r. odnosząca się do koordynacji procedur udzielania zamówień publicznych na usługi, Dz.Urz. UE L 209 z 24 lipca 1992 r., s. 1. 
czy potrzebne są szczególne środki bezpieczeństwa, przy czym owym państwom członkowskim przysługuje w tym zakresie szeroki zakres uznania (pkt 55-57 wyroku). W szczególności Austria zwracała uwagę na trzy czynniki wiążące udzielanie przedmiotowych zamówień $\mathrm{z}$ jej podstawowymi interesami w zakresie bezpieczeństwa publicznego:

- zapewnienie autentyczności i prawidłowości dokumentów tożsamości (co jest konieczne z uwagi na znaczenie ustalenia tożsamości osoby dla prawidłowego funkcjonowania instytucji państwowych, a także na uniknięcie ryzyka fałszowania, w szczególności w ramach walki z terroryzmem i przestępczością),

- zapewnienie ochrony wrażliwych danych osobowych (w zakresie, w jakim dokumenty tożsamości zawierają tego rodzaju dane, $\mathrm{w}$ tym dane biometryczne, dla ochrony tych dokumentów konieczne są wysokie wymogi bezpieczeństwa; naruszenie takich danych powinno bowiem być uważane, w szczególności w kontekście walki z terroryzmem, za stanowiące zagrożenie dla wewnętrznego bezpieczeństwa publicznego),

- zagwarantowanie bezpieczeństwa dostaw (w przypadku braku możliwości dostarczenia potrzebnej liczby paszportów zaistniałaby konieczność wydrukowania paszportów tymczasowych, co wiązałoby się z wystąpieniem ryzyka w zakresie bezpieczeństwa).

W ocenie Austrii centralizacja wskazanych świadczeń u jednego usługodawcy jest kluczowym elementem strategii w dziedzinie bezpieczeństwa, stanowi bowiem odpowiedni środek dla zapobieżenia rozprzestrzenianiu się szczególnie wrażliwych informacji dotyczących bezpieczeństwa. Państwo to utrzymuje też, że - jak wynika $\mathrm{z}$ art. 3 ust. 2 rozporządzenia nr 2252/2004 ${ }^{7}$ a w szczególności $\mathrm{z}$ wymogu wyznaczenia jednego organu odpowiedzialnego za drukowanie paszportów i dokumentów podróży - nie mogą one być wykonywane przez różne organy. Ponadto umiejscowienie zakładu na terytorium Austrii ma zapobiec rozprzestrzenianiu się znajomości środków zabezpieczenia wśród innych wykonawców działających w Austrii lub w innym państwie członkowskim UE, a także ma na celu skuteczniejszą kontrolę tej drukarni przez władze krajowe w ramach ich administracyjnych uprawnień kontrolnych. Kontrola sądowa ex post w postaci sankcji za naruszenie warunków bezpieczeństwa nie stanowiłaby, w ocenie Austrii, równie skutecznego środka. Powierzenie realizacji zamówień podmiotowi $\mathrm{z}$ innego państwa wiązałoby się również z ryzykiem ujawnienia przez ten podmiot wrażliwych informacji w związku $z$ interwencją organów lub służb wywiadowczych państwa macierzystego tego podmiotu.

7 Rozporządzenie Rady (WE) nr 2252/2004 z 13 grudnia 2004 r. w sprawie norm dotyczących zabezpieczeń i danych biometrycznych w paszportach i dokumentach podróży wydawanych przez Państwa Członkowskie, Dz.Urz. UE L 385 z 29 grudnia 2004 r., s. 1. 
W ocenie Komisji Europejskiej wskazane wyżej przepisy austriackie naruszają dyrektywę 2004/18 oraz zastąpioną przez nią dyrektywę 92/50. Komisja zwróciła uwagę, że szacunkowe kwoty dotyczące rozważanych zamówień (poza legitymacją pirotechnika) przekraczają progi mające zastosowanie na mocy dyrektyw 92/50 i 2004/18, a więc powinny być objęte wymaganymi przez nie procedurami udzielania zamówień publicznych (art. 8 dyrektywy 92/50 w związku z jej art. 11-37 oraz w art. 20 dyrektywy 2004/18 w związku z jej art. 23-55). Przepisy dopuszczające wyłączenie zamówień spod reżimu dyrektyw powinny być interpretowane w sposób zwężający. W szczególności sam fakt powołania się na podstawowe interesy bezpieczeństwa nie może stanowić wystarczającej podstawy odstąpienia od wymogów wynikających z TFUE czy z dyrektyw. W ocenie Komisji Europejskiej to na Austrii spoczywa obowiązek wykazania, że przetarg jest całkowicie niemożliwy ze względu na to, że poważnie zagroziłby przestrzeganiu obowiązku zachowania poufności, a także środkom dotyczącym bezpieczeństwa i kontroli. Zdaniem KE Austria nie wykazała istnienia powyższych okoliczności. Można co prawda uznać, że zapewnienie autentyczności i prawidłowości dokumentów stanowiących dowody tożsamości osób, ochrony danych osobowych oraz dostaw dla celów drukowania danych dokumentów leży w interesie ogólnym, nie należy jednak w pełni utożsamiać środków służących interesowi ogólnemu ze środkami koniecznymi ze względu na ochronę podstawowych interesów bezpieczeństwa. Ponadto KE twierdzi, że zabezpieczenie wskazanych przez Austrię interesów może zostać skutecznie osiągnięte za pomocą bardziej liberalnych środków. Drukowanie dokumentów może być powierzone innym drukarniom, nawet $\mathrm{z}$ innych państw członkowskich, albowiem poufny charakter przetwarzanych danych koniecznych do drukowania dokumentów mógłby zostać zagwarantowany przez obowiązek zachowania poufności nałożony na przedsiębiorstwa uczestniczące w postępowaniu o udzielenie zamówienia. Centralizacja wykonania mogłaby zostać osiągnięta poprzez objęcie druku wszystkich zabezpieczonych dokumentów przetargiem, przy czym możliwości kontrolowania przez władze austriackie mogłyby zostać zapisane w umowie zawartej z wybranym przedsiębiorstwem. Komisja wskazuje też, że władze austriackie mogą również udzielać zamówień na druk zabezpieczonych dokumentów przedsiębiorstwom innym niż ÖSD, zwłaszcza jeżeli ÖSD nie jest w stanie wykonać powyższych zamówień. Pozwala to na zakwestionowanie wymogu szczególnego zaufania, jakim cieszy się ÖSD, jako rzekomo niezbędnego warunku przyznania zamówienia.

\section{Wyrok}

Trybunał Sprawiedliwości UE potwierdził przedstawiony przez Austrię argument, że to do państw członkowskich należy określenie ich podstawowych interesów bezpieczeństwa. W rozpatrywanym przypadku do austriackich organów należy więc określenie środków bezpieczeństwa koniecznych w celu ochrony 
bezpieczeństwa publicznego tego państwa członkowskiego w ramach drukowania dokumentów tożsamości i innych dokumentów tożsamości, takich jak dokumenty w sprawie C-187/16. Z drugiej jednak strony środki, które przyjmują państwa członkowskie w ramach słusznych względów interesu narodowego, nie są wyjęte $\mathrm{z}$ zakresu stosowania prawa Unii z tego tylko względu, że są podejmowane m.in. $w$ interesie bezpieczeństwa publicznego lub obrony narodowej. Oznacza to, że choć art. 4 ust. 2 dyrektywy 92/50 i art. 14 dyrektywy 2004/18 pozostawiają państwom członkowskim margines swobody w podejmowaniu decyzji odnośnie do środków uznanych za niezbędne w celu ochrony podstawowych interesów ich bezpieczeństwa, artykuły te nie mogą być interpretowane w taki sposób, że przyznają one państwom członkowskim uprawnienie do odstąpienia od postanowień TFUE wyłącznie poprzez powołanie się na wyżej wspomniane interesy. To na państwie członkowskim spoczywa więc obowiązek wykazania, że stosowanie tych uregulowań jest konieczne dla ochrony jego podstawowych interesów bezpieczeństwa. Wymóg ów występuje również w takim zakresie, w jakim państwo członkowskie powołuje się na art. 346 ust. 1 lit. a TFUE. W omawianym przypadku TSUE uznał więc, że to Austria musiała wykazać, że potrzeba ochrony tych interesów nie mogła być zrealizowana w postępowaniu przetargowym takim jak przewidziane w dyrektywach 92/50 i 2004/18. Ponadto Trybunał potwierdził stanowisko wynikające $\mathrm{z}$ jego utrwalonego orzecznictwa, zgodnie z którym odstępstwa dotyczące swobód podstawowych $w$ ramach rynku wewnętrznego muszą być przedmiotem wykładni ograniczającej.

Odnosząc się do argumentu Austrii, zgodnie z którym centralizacja wykonania niektórych dokumentów jest konieczna $z$ uwagi na ochronę podstawowych interesów bezpieczeństwa państwa, Trybunał stwierdził, że cel ten nie uzasadnia odstąpienia od procedury przetargowej. Scentralizowany podmiot może bowiem zostać wyłoniony w procedurze przetargowej.

Jeżeli chodzi o możliwość zapewnienia skutecznej kontroli administracyjnej, zdaniem Trybunału Republika Austrii nie wykazała, że jedynie kontrole administracyjne, jakie względem ÖSD mogą przeprowadzić władze austriackie na mocy $\$ 6$ ust. 3 spornej ustawy austriackiej, są w stanie zapewnić wymaganą poufność i że w tym celu niezbędne byłoby odstąpienie od stosowania przepisów dotyczących udzielania zamówień przewidzianych w dyrektywach 92/50 i 2004/18. Kontrole tego typu mogłyby bowiem, według TSUE, być przeprowadzane także w innych przedsiębiorstwach posiadających siedzibę (etablies) w Austrii. Również austriackie stanowisko, jakoby kontrola przestrzegania poufności informacji przekazywanych w celu wydrukowania omawianych dokumentów urzędowych była gorzej zapewniona, gdyby owo drukowanie powierzono, $\mathrm{w}$ wyniku postępowania przetargowego, innym przedsiębiorstwom, na które nałożone zostałyby w drodze postanowień umów podlegających przepisom prawa cywilnego środki poufności i bezpieczeństwa, nie zostało $\mathrm{w}$ ocenie TSUE wystarczająco uzasad- 
nione. Co więcej, zdaniem TSUE, nie wykazano też, że taka kontrola nie mogłaby być równie skuteczna niezależnie od tego, czy siedziby owych przedsiębiorstw znajdowałyby się w Austrii, czy w innych państwach członkowskich. Przykładowo, możliwy do przewidzenia w ramach postępowania o udzielenie zamówienia byłby obowiązek wyrażenia przez wybranego wykonawcę zgody na kontrole bezpieczeństwa, kontrole lub inspekcje w siedzibie przedsiębiorstwa, niezależnie od tego, czy jego siedziba znajduje się w Austrii czy w innym państwie członkowskim. Podobnie możliwe byłoby nałożenie w ten sposób obowiązku przestrzegania nawet bardzo wysokich wymogów technicznych w zakresie poufności $\mathrm{w}$ ramach realizacji omawianych zamówień.

Również w odniesieniu do gwarancji dostaw oraz niezawodności i godnego zaufania charakteru wykonawcy TSUE uznał, że Austria nie wykazała niemożliwości ich zapewnienia w ramach procedury przetargowej. Możliwe jest bowiem określenie odpowiednich wymogów - w tym dotyczących zachowania tajemnicy i wymaganych cech wykonawcy - w warunkach przetargu, a także zażądanie od potencjalnych kandydatów dowodów poświadczających spełnienie tych warunków. Odnosząc się do argumentu, że powierzenie realizacji zamówień podmiotowi z innego państwa wiązałoby się z ryzykiem ujawnienia przez ten podmiot wrażliwych informacji w związku z interwencją organów lub służb wywiadowczych państwa macierzystego, Trybunał stwierdził, że również tego ryzyka można uniknąć bez wyłączania zamówienia spod reżimu zamówień publicznych. Zamawiający mógłby bowiem wskazać wśród warunków przetargu ogólny obowiązek zachowania poufności przez wykonawcę i wykluczyć z procedury udzielania zamówienia te przedsiębiorstwa, które nie byłyby w stanie zapewnić odpowiednich gwarancji co do poszanowania tego obowiązku, w szczególności z uwagi na przepisy państwa członkowskiego, z którego pochodzą.

Konkludując, Trybunał doszedł do wniosku, że nieprzestrzeganie procedur udzielania zamówień przewidzianych przez przedmiotowe dyrektywy wydaje się nieproporcjonalne w stosunku do zamierzonego celu. W związku z tym Republika Austrii nie może skutecznie powoływać się na art. 346 ust. 1 lit. a TFUE, art. 4 ust. 2 dyrektywy 92/50 i art. 14 dyrektywy 2004/18 w celu uzasadnienia nieprzestrzegania procedur udzielania zamówień przewidzianych przez te dwie dyrektywy. Austria uchybiła więc zobowiązaniom, które na niej ciążyły na mocy art. 4 ust. 2 i art. 8 dyrektywy 92/50 w związku z art. 11-37 tej dyrektywy oraz na mocy art. 14 i 20 dyrektywy 2004/18 w związku z art. 23-55 tej dyrektywy.

Odmienne stanowisko TSUE zajął jedynie w odniesieniu do wytwarzania legitymacji pirotechnika. Szacunkowa wartość zamówienia jest w tym wypadku na tyle niska, że nie przekracza progów przewidzianych przez dyrektywy 92/50 i 2004/18. Z tego powodu zamówienie to nie podlega reżimowi określonemu w tych dyrektywach. Nie oznacza to jednak, że tego rodzaju zamówienia są wyłączone spod traktatowych reguł obowiązujących na unijnym rynku wewnętrznym, w szczególności w zakresie równego traktowania i niedyskryminacji ze 
względu na przynależność państwową, a także wynikającego z nich obowiązkowi przejrzystości. Reguły te mają zastosowanie do zamówień publicznych pod warunkiem, że zamówienia te mają niewątpliwe znaczenie transgraniczne. W omawianej sprawie Trybunał oddalił skargę w tym zakresie, ponieważ Komisja nie wykazała, aby wspomniane zamówienie stanowiło niewątpliwy przedmiot zainteresowania transgranicznego.

Wydanie wyroku zostało poprzedzone wygłoszeniem opinii przez rzecznika generalnego. Całościowe jej omówienie wykraczałoby poza granice niniejszej opinii, niemniej warto uzupełnić powyższą prezentację wyroku o niektóre zagadnienia istotne z perspektywy opiniowanego projektu'

Rzecznik zgadza się ze stanowiskiem Austrii, że stosowanie władczych uprawnień kontrolnych może być konieczne $\mathrm{w}$ celu ochrony podstawowych interesów w zakresie bezpieczeństwa krajowego, ponieważ są one bardziej skuteczne w działaniu niż prawa kontrolne uzgodnione w umowie cywilnoprawnej. Niemniej, jej zdaniem: ta okoliczność sama $w$ sobie nie uzasadnia całkowitego pomijania istniejących wymogów prawa Unii w odniesieniu do udzielania zamówień publicznych i a priori brania pod uwage jako wykonawcę zawsze tylko jednego określonego przedsiębiorstwa. Zdaniem rzecznik Austria powinna zapewnić równowagę między uprawnieniami kontrolnymi koniecznymi dla ochrony bezpieczeństwa $\mathrm{z}$ jednej strony i swoimi zobowiązaniami unijnymi z drugiej strony, przy czym do dopuszczalnych rozwiązań rzecznik zalicza:

- zamiast całkowitego wyłaczenia $z$ przetargu przedsiębiorstw $z$ siedziba $w$ innych państwach stronach porozumienia EOG Austria mogłaby $w$ razie potrzeby zobowiazać wszystkich zainteresowanych do zrealizowania spornego zamówienia na druk $w$ razie jego udzielenia przez zakład położony $w$ kraju, przetwarzania gromadzonych przy tym danych osobowych wyłacznie w kraju oraz nieprzesyłania takich danych oraz informacji dotyczacych bezpieczeństwa przez zagraniczne linie danych lub serwery lub nieprzekazywania ich do części przedsiębiorstwa położonych za granica lub zagranicznym władzom;

- oraz zamiast przewidywać uprawnienia kontrolne z zakresu władzy publicznej (...) wyłacznie wobec Staatsdruckerei, ustawodawca austriacki mógłby ogólnie upoważnić odpowiedzialne organy państwowe do przeprowadzania takich kontroli we wszystkich przedsiębiorstwach mających zakłady $w$ kraju, jeżeli wykonuja one tam istotne pod względem bezpieczeństwa zamówienia na drukowanie.

8 Szersze przedstawienie stanowiska rzecznik generalnej zostało zawarte w opinii BAS do druku sejmowy nr 2153, P. Bachmat, M. Jaśkowski, Ocena rządowego projektu ustawy o dokumentach publicznych (druk sejmowy nr 2153), „Zeszyty Prawnicze BAS” 2018, nr 1(57), s. 115-130. 
Wynikające z powyższego rozwiązania ograniczenia swobody przepływu usług byłyby, zdaniem rzecznik, dopuszczalne w świetle orzecznictwa TSUE ${ }^{9}$ z uwagi na konieczność przeprowadzania kontroli administracyjnych.

$\mathrm{Na}$ uwagę zasługuje również argument podniesiony przez Austrię na rozprawie, a mianowicie: zagraniczne przedsiębiorstwa nie mogą całkowicie uchylić się od ingerencji władz swojego kraju pochodzenia i częściowo są nawet zobowiązane do współpracy z tamtejszymi służbami wywiadowczymi, i to także wówczas, gdy wykonują zamówienia publiczne za pośrednictwem zagranicznego zakładu. Dlatego takie przedsiębiorstwa nie mogą być brane pod uwagę jako wykonawcy wrażliwych zamówień na druk, takich jak te w niniejszej sprawie. Również ten argument nie przekonał rzecznik. Warto przytoczyć jej uzasadnienie: zgodnie $z$ utrwalonym orzecznictwem przepisy krajowe sa odpowiednie do zapewnienia osiągnięcia zamierzonego celu jedynie wtedy, gdy rzeczywiście odzwierciedlaja zamiar osiagnnięcia tego celu w sposób spójny i systematyczny. W niniejszym wypadku Austria, o ile wiadomo, nie podjęła żadnych środków, które skutecznie mogłyby uniemożliwić, aby Staatsdruckerei dostała się pod kontrole zagranicznych wspólników lub stała się spółką zależna zagranicznej osoby prawnej. Państwo austriackie nie wynegocjowało sobie $w$ Staatsdruckerei motywowanych względami polityki bezpieczeństwa uprawnień do współdecydowania w formie szczególnej akcji („złota akcja") ani nie poddało zbywania udziałów w Staatsdruckerei żadnym ograniczeniom ze względów polityki bezpieczeństwa.

\section{Odniesienie wyroku TSUE do opiniowanego projektu}

\section{Przedmiot opiniowanych przepisów}

Artykuł 17 projektu przewiduje, że blankiety dokumentów publicznych, o których mowa w art. 5 ust. 2 projektu, mają być wytwarzane przez jednoosobową spółkę Skarbu Państwa (dalej: Spółka), której przedmiotem działalności jest wytwarzanie blankietów dokumentów i druków zabezpieczonych, mającą siedzibę oraz zakład produkcyjny, w którym są wytwarzane blankiety dokumentów publicznych, na terytorium Rzeczypospolitej Polskiej. Art. 5 ust. 2 projektu zawiera wyliczenie dokumentów publicznych kategorii pierwszej, tj. w myśl ustawy dokumentów najistotniejszych z punktu widzenia bezpieczeństwa państwa. Jest to obszerny katalog obejmujący ponad 40 pozycji. Zgodnie $z$ art. 17 ust. 6 projektu, jeżeli wytworzenie przez Spółkę blankietów dokumentu publicznego, o którym mowa w art. 5 ust. 2, zgodnie z warunkami określonymi przez emitenta dokumentu publicznego nie jest możliwe, blankiety tego dokumentu publicznego mogą być wytwarzane przez inny podmiot, posiadający świadectwo bezpieczeństwa przemysłowego

9 Wyrok TSUE z 4 grudnia 1986 r., sygn. akt 205/84, Komisja v. Niemcy, EU:C:1986:463, pkt 52 w związku z pkt 54 . 
pierwszego stopnia oraz zakład produkcyjny, w którym będzie wytwarzany blankiet tego dokumentu publicznego, na terytorium Rzeczypospolitej Polskiej.

Jednocześnie art. 64 projektu, przez zmianę art. 4 ust. 5c ustawy z 29 stycznia 2004 r. - Prawo zamówień publicznych (dalej: u.p.z.p.), zmierza do modyfikacji katalogu zamówień, do których nie stosuje się ustawy - Prawo zamówień publicznych. Zgodnie z obecnym brzmieniem tego przepisu ustawy tej nie stosuje się do zamówień dotyczących wytwarzania i dystrybucji dokumentów publicznych (i ich personalizacji), druków o strategicznym znaczeniu dla bezpieczeństwa państwa oraz znaków akcyzy. Zgodnie z projektem przedmiotowe wyłączenie miałoby obejmować zamówienia dotyczące wytwarzania i personalizacji lub indywidualizacji dokumentów wymienionych $\mathrm{w}$ art. 5 ust. 2 opiniowanego projektu, a ponadto zamówienia dotyczące wytwarzania znaków akcyzy, znaków legalizacyjnych i nalepek kontrolnych, kart do głosowania, znaków holograficznych umieszczanych na zaświadczeniach o prawie do głosowania, a także układu mikroprocesorowego z oprogramowaniem służącym do zarządzania dokumentami publicznymi, systemów i baz informatycznych niezbędnych do zastosowania dokumentów publicznych, o których mowa w art. 5 ust. 2 projektu. Należy zaznaczyć, że zgodnie z obowiązującym stanem prawnym wykaz dokumentów publicznych i druków o strategicznym znaczeniu dla bezpieczeństwa państwa jest określany przez Radę Ministrów w drodze rozporządzenia (art. 4aa u.p.z.p. przepis ten ma zostać uchylony na mocy art. 64 pkt 2 opiniowanego projektu). Obecnie wykaz taki jest zawarty w rozporządzeniu Rady Ministrów w sprawie wykazu dokumentów publicznych i druków o strategicznym znaczeniu dla bezpieczeństwa państwa z 20 lipca 2016 r. (Dz.U. poz. 1089; 2017, poz. 1996). Projektowana zmiana polega więc na przeniesieniu tej regulacji na poziom ustawowy, jak również na poszerzeniu jej zakresu o niektóre dokumenty. Modyfikacje przewidziane $\mathrm{w}$ art. 62, 69 i 70 projektu zmierzają do uchylenia przepisów przyznających określonym $\mathrm{w}$ nich ministrom kompetencje $\mathrm{w}$ zakresie wyboru dostawców druków i usług i stanowią konsekwencję wskazanych wyżej zmian.

\section{Różnice między stanem prawnym i faktycznym w sprawie C-187/16 a opiniowanym projektem}

Oba rozpatrywane przypadki charakteryzują się daleko idącym podobieństwem. W obu sytuacjach ustawodawca zastrzega możliwość wytwarzania określonych dokumentów tylko dla określonego indywidualnie podmiotu (lub zmierza do tego), będącego spółką prawa handlowego, z pominięciem procedury przetargowej, powołując się przy tym na konieczność ochrony bezpieczeństwa państwa. W obu też sytuacjach w pewnych okolicznościach dopuszczalne jest wyjątkowo powierzenie realizacji zlecenia innym podmiotom.

Między tymi przypadkami istnieją jednak również pewne różnice, $\mathrm{z}$ których najistotniejsze wiążą się z (a) wejściem w życie dyrektywy 2014/24 oraz (b) inną strukturą własnościową ÖSD i Spółki, o której mówi art. 17 opiniowanego projektu. 


\section{- Problem aktualności wyroku w świetle dyrektywy 2014/24}

$\mathrm{Z}$ uwagi na ramy czasowe objęte skargą Komisji, ocena zgodności z prawem UE przepisów austriackich została przeprowadzona przez TSUE w świetle dyrektyw 92/50 i 2004/18. Obecnie żadna z tych dyrektyw nie obowiązuje, a ujęta w nich wcześniej problematyka jest uregulowana w dyrektywie 2014/24. Rodzi to pytanie o aktualność wyroku opartego na nieobowiązujących już przepisach. W związku z tym należy zwrócić uwagę, że art. 15 dyrektywy 2014/24, podobnie jak odpowiadające mu art. 4 dyrektywy 92/50 i art. 10 oraz 14 dyrektywy 2004/18, dopuszcza wyłączenie stosowania dyrektywy z uwagi na te same względy, jest jednak sformułowany w inny sposób. Wcześniejsze dyrektywy wyłączały swoje zastosowanie w odniesieniu do zamówień publicznych w trzech przypadkach (1) zamówienia określone jako tajne, (2) zamówienia, których realizacji musiały towarzyszyć szczególne środki bezpieczeństwa zgodnie z przepisami ustawowymi, wykonawczymi i administracyjnymi obowiązującymi w danym państwie członkowskim, (3) jeżeli wymagała tego ochrona podstawowych interesów (bezpieczeństwa) tego państwa.

Dyrektywa 2014/24 przewiduje wyłączenie jej zastosowania zasadniczo na podstawie tych samych przesłanek (ochrona podstawowych interesów danego państwa członkowskiego w zakresie bezpieczeństwa - art. 15 ust. 2; konieczność zachowania tajności lub szczególnych środków bezpieczeństwa - art. 15 ust. 3), jednak uwagę zwraca opatrzenie ich dodatkowymi warunkami.

W odniesieniu do klauzuli ochrony podstawowych interesów danego państwa członkowskiego w zakresie bezpieczeństwa dyrektywa uściśla, że powołanie się na nią jest dopuszczalne tylko pod warunkiem, iż ochrona ta nie może zostać zagwarantowana: przez mniej inwazyjne środki, na przykład przez nałożenie wymogów mających na celu ochrone poufnego charakteru informacji udostępnianych przez instytucje zamawiajaca $w$ trakcie trwania postepowania o udzielenie zamówienia zgodnie z niniejsza dyrektywa. Podobnie powołanie się na tajność lub konieczność stosowania szczególnych środków bezpieczeństwa jest możliwe pod warunkiem, że nie mogą one zostać zagwarantowane za pomocą mniej inwazyjnych środków, takich jak, przykładowo, wspomniane wyżej określenie odpowiednich wymogów w postępowaniu zamówieniowym. Zmiany te, mimo iż pozornie zaostrzają możliwość wyłączenia niektórych zamówień spod reżimu dyrektywy, w istocie nie stanowią istotnej modyfikacji. Zasada zwężającej interpretacji wyjątków oraz obowiązek stosowania środków o charakterze proporcjonalnym jest stanowiskiem utrwalonym w orzecznictwie TSUE ${ }^{10}$. Oznacza to, że odstępstwa wprowadzane przez państwa w ramach rynku wewnętrznego powinny być nie tylko adekwatne w odniesieniu do założonego celu, ale również niezbędne (tj. nie mogą istnieć środki, które umożliwiałyby osiągnięcie tego samego celu, a jednocześnie w mniejszym stopniu ograniczałyby swobody rynku

10 Zob. np. omawiany wyrok C-187/16, pkt 77 i 95. 
wewnętrznego). Artykuł 15 ust. 2 i 3 zawiera podręcznikowy przykład kodyfikacji tych zasad w szczególnym przypadku.

Podsumowując, obecnego brzmienia tych przepisów nie należy interpretować jako dalej idącego ograniczenia możliwości powołania się przez państwa członkowskie na zawarte tam klauzule. $\mathrm{W}$ związku z tym omawiany wyrok zachowuje aktualność również w odniesieniu do obecnego stanu prawnego.

\section{- Znaczenie różnej struktury własnościowej ÖSD i Spółki}

Jak wskazuje rzecznik generalna w opinii w sprawie C-187/16: należy zauważyć, że $w$ niniejszym przypadku nie jest możliwe zastosowanie orzecznictwa dotyczacego transakcji typu „in-house”, ponieważ Republika Austrii nie sprawuje już kontroli nad Staatsdruckerei tak jak nad własna jednostka administracji. Chodzi raczej o przedsiębiorstwo zorganizowane wyłącznie na zasadach prawa prywatnego, które w pełni stanowi własność osób prywatnych (pkt 29 opinii). Opiniowany projekt przewiduje natomiast powierzenie wykonywania dokumentów jednoosobowej spółce Skarbu Państwa. Należy w związku z tym zastanowić się, czy ta różnica ma znaczenie z perspektywy kwestii stanowiących przedmiot niniejszej opinii.

Prawo UE nie zawiera ogólnego nakazu nabywania przez państwa członkowskie dóbr na rynku. Decyzje co do zakresu prowadzenia działalności gospodarczej przez państwo mają polityczny charakter i pozostają w gestii państw członkowskich $\mathrm{z}$ uwagi na treść art. 345 TFUE. Niemniej przedsiębiorstwa prywatne i państwowe powinny być traktowane równo, zgodnie z unijnymi regułami konkurencji. Jeżeli chodzi o działania $\mathrm{w}$ interesie publicznym, państwa mają więc swobodę podjęcia decyzji, czy dane dobro zakupią na rynku czy wytworzą ${ }^{11}$. Zgodnie z tym podejściem dyrektywa 2014/24 przewiduje, że przy spełnieniu wskazanych w niej warunków zamówienia publiczne między podmiotami sektora publicznego są wyłączone spod jej reżimu. Artykuł 12 dyrektywy określa trzy warunki konieczne dla skorzystania z tego wyłączenia: (1) instytucja zamawiająca sprawuje nad daną osobą prawną kontrolę podobną do kontroli, jaką sprawuje nad własnymi jednostkami; (2) ponad 80\% działalności kontrolowanej osoby prawnej jest prowadzone w ramach wykonywania zadań powierzonych jej przez instytucję zamawiającą sprawującą kontrolę lub przez inne osoby prawne kontrolowane przez tę instytucję zamawiającą oraz (3) w kontrolowanej osobie prawnej nie ma bezpośredniego udziału kapitału prywatnego, $\mathrm{z}$ wyjątkiem form udziału kapitału prywatnego o charakterze niekontrolującym i nieblokującym, wymaganych na mocy krajowych przepisów ustawowych, zgodnie z traktatami, oraz niewywierających decydującego wpływu na kontrolowaną osobę prawną.

Analizując przywołane przepisy, trzeba mieć świadomość, że chociaż regulacje przewidujące wyłączenie z zakresu stosowania dyrektywy zamówień między

11 A. Sánchez Graells, Public Procurement and the EU Competition Rules, Oxford 2011, s. $232-233$. 
jednostkami sektora publicznego są nowym rozwiązaniem w porównaniu z poprzednio obowiązującymi dyrektywami, to jednak w zasadniczym zakresie jest to kodyfikacja dotychczasowego orzecznictwa TSUE. Interpretując art. 12 dyrektywy 2014/24, należy więc uwzględniać wcześniejsze orzecznictwo Trybunału. $\mathrm{Z}$ drugiej jednak strony art. 12 stanowi nowy przepis, który jako taki dotychczas nie doczekał się interpretacji w orzecznictwie TSUE. Wcześniejsze orzecznictwo należy więc brać pod uwagę tylko w stopniu, w jakim pozostaje ono aktualne w świetle art. 12 dyrektywy 2014/24 ${ }^{12}$.

Z uwagi na treść opiniowanego projektu potrzebna jest ocena, czy powierzenie wytwarzania blankietów dokumentów publicznych jednoosobowej spółce Skarbu Państwa, o której mowa w art. 17 ust. 1 projektu, może zostać objęte wyłączeniem wynikającym z art. 12 ust. 1 dyrektywy 2014/24. Trzeba jednak zastrzec, że na obecnym etapie przeprowadzenie oceny zgodności rozwiązań zawartych w projekcie jest utrudnione, ponieważ ocena statusu podmiotu wykonującego zamówienie powinna brać pod uwagę nie tylko przepisy prawa ogólnie obowiązującego, ale również regulacje wewnętrzne, a także okoliczności faktyczne, dotyczące ewentualnej autonomii danego podmiotu i jej zakresu ${ }^{13}$. Przedmiot niniejszej analizy jest natomiast ograniczony do treści projektu ustawy.

W odniesieniu do formy prawnej Spółki należy wskazać, że kontrolowana osoba prawna może być spółką, w tym - spółką prawa handlowego. Wskazuje na to art. 12 ust. 1 dyrektywy 2014/24 (osoba prawa prywatnego lub publicznego), a także art. 12 ust. 1 lit. c tej dyrektywy (przewidujący możliwość posiadania udziałów w takim podmiocie). Również orzecznictwo TSUE potwierdza możliwość objęcia wyłączeniem - jako transakcji wewnętrznych - zamówień realizowanych przez spółki ${ }^{14}$.

W odniesieniu do kryterium kontroli dyrektywa precyzuje, że: [i]nstytucja zamawiajaca sprawuje nad dana osoba prawna kontrole podobna do kontroli, jaka sprawuje nad własnymi jednostkami $w$ rozumieniu akapitu pierwszego lit. a, jeżeli wywiera decydujący wpływ zarówno na cele strategiczne, jak i na istotne decyzje kontrolowanej osoby prawnej (art. 12 ust. 1 akapit 2 dyrektywy 2014/24). Z orzecznictwa TSUE wynika, że posiadanie całości kapitału zakładowego spółki

12 Przykładowo, w świetle art. 12 ust. 1 lit. c dyrektywy 2014/24 nieaktualne jest stanowisko, zgodnie z którym: jest wykluczone, by instytucja zamawiająca mogła sprawować nad koncesjonariuszem kontrole podobna do tej, która sprawuje nad własnymi służbami, jeśli przedsiębiorstwo prywatne posiada udziały w kapitale tego koncesjonariusza, wyrażone np. w wyrokach TSUE z 13 listopada 2008 r. w sprawie C-324/07, Coditel Brabant SA, ECLI:EU:C:2008:621 (pkt 30), oraz z 10 września 2009 r. w sprawie C-573/07, Sea, ECLI:EU:C:2009:532 (pkt 46).

13 Wyrok TSUE z 11 maja 2006 r. w sprawie C-340/04, Carbotermo, ECLI:EU:C:2006:308, pkt 36; W. Hartung i in., Dyrektywa 2014/24/UE w sprawie zamówień publicznych. Komentarz do art. 12, Warszawa 2015, nb 15.

14 Wyrok TSUE z 11 maja 2006 r. w sprawie C-340/04, Carbotermo, pkt 37. 
pozwala przyjąć, iż instytucja zamawiająca sprawuje nad tą spółką kontrolę analogiczną do sprawowanej nad własnymi służbami ${ }^{15}$. Nie jest to jednak argument przesądzający. Przeciwko takiemu wnioskowi mogą bowiem przemawiać następujące okoliczności: szeroki zakres uprawnień zarządu spółki (obejmujący pełne kompetencje do prowadzenia spraw z zakresu zwykłych czynności spółki oraz spraw przekraczających ten zakres), niepodlegający szczególnym kompetencjom nadzorczym; znaczna autonomia spółki w stosunku do własnych akcjonariuszy ${ }^{16}$; brak szczególnego prawa głosu w celu ograniczenia swobody działania przyznanej zarządowi ${ }^{17}$; szeroki zakres przedmiotowy i terytorialny działalności spółki $^{18}$. Sama tylko kontrola, jaką prawo spółek przyznaje większości akcjonariuszy, może więc być niewystarczająca, jeżeli chodzi o możliwości wywierania wpływu na decyzje podejmowane przez spółkę ${ }^{19}$.

Odnosząc powyższe kryteria do Spółki, należy zauważyć, że ma ona mieć szczególny charakter. Jako jednoosobowa spółka Skarbu Państwa będzie państwową osobą prawną ${ }^{20}$. W odniesieniu do zakresu uprawnień zarządu, szczególnego prawa głosu w celu ograniczenia swobody działania przyznanej zarządowi oraz stopnia autonomii Spółki wobec akcjonariuszy projekt ustawy nie przewiduje specjalnych rozwiązań. Niemniej zagadnienia te - w zakresie dopuszczalnym przez prawo - mogą zostać określone w statucie Spółki, przy czym Skarb Państwa będzie miał wyłączne prawo decydowania o treści tego statutu. Ponadto w przypadku Spółki będą miały zastosowanie przepisy ustawy o zasadach zarządzania mieniem państwowym, w szczególności jej art. 17 dotyczący przyjęcia reguł wymagających zgody walnego zgromadzenia w przypadku określonych rozporządzeń mieniem Spółki. Zważywszy, że art. 17 ust. 1 projektu określa przedmiot działalności Spółki (jednoosobowa spółka Skarbu Państwa, której przedmiotem działalności jest wytwarzanie blankietów dokumentów i druków zabezpieczonych), należy zakwalifikować ją jako spółkę realizującą misję publiczną w rozumieniu ustawy o zasadach zarządzania mieniem państwowym (zgodnie $\mathrm{z}$ art. 1 pkt 8 lit. a tej ustawy). W konsekwencji znajdzie tu zastosowanie art. 9 ust. 2 przywołanej ustawy, zgodnie z którym w spółce realizującej misję publiczną wykonywanie praw z akcji należących do Skarbu Państwa lub państwowej osoby prawnej odbywa się na zasadach prawidłowej gospodarki, w szczególności w celu efektywnej realizacji misji publicznej realizowanej przez tę spółkę. Rozważając hipotetycznie ewentualne objęcie Spółki dodatkowym, szczególnym

15 Ibidem, pkt 37.

16 Wyrok TSUE z 3 października 2005 r. w sprawie C-458/03, Parking Brixen, ECLI:EU:C:2005:605, pkt 68.

17 Wyrok TSUE z 11 maja 2006 r. w sprawie C-340/04, Carbotermo, pkt 38.

18 Wyrok TSUE z 3 października 2005 r. w sprawie C-458/03, Parking Brixen, pkt 67.

19 Wyrok TSUE z 11 maja 2006 r. w sprawie C-340/04, Carbotermo, pkt 38.

20 Zgodnie z art. 3 ust. 3 pkt 2 ustawy z 16 grudnia 2016 r. o zasadach zarządzania mieniem państwowym, Dz.U. poz. 2259, ze zm. 
nadzorem ze strony państwa, należy mieć na uwadze, że powinno ono mieć racjonalne uzasadnienie. Wprowadzenie takiej kontroli tylko w celu wyłączenia przedmiotowych zamówień spod reżimu dyrektywy 2014/24 mogłoby natomiast zostać uznane za działanie zmierzające do obejścia prawa $\mathrm{UE}^{21}$.

Odnosząc się do poglądu TSUE, zgodnie z którym: sama tylko kontrola, jaką prawo spółek przyznaje większości akcjonariuszy może być niewystarczająca, można stwierdzić, że, po pierwsze, jak wskazano wyżej, z orzecznictwa wynika również założenie, iż posiadanie całości kapitału zakładowego spółki oznacza możliwość sprawowania nad tą spółką kontroli analogicznej do sprawowanej nad własnymi służbami; po drugie, zastrzeżenie nie zostało sformułowane przez TSUE w sposób kategoryczny („może być niewystarczająca”) i należy traktować je raczej jako rezultat oceny okoliczności danego przypadku, a nie ogólną wytyczną, która wiązałaby na przyszłość.

W odniesieniu do zakresu działalności spółki należy uznać, że to kryterium, wynikające uprzednio z orzecznictwa, zostało obecnie sprecyzowane w art. 12 ust. 1 lit. b dyrektywy 2014/24. W zakresie, w jakim ten aspekt dotyczy sytuacji faktycznej, nie podlega więc ocenie w niniejszej opinii. Niemniej należy zwrócić uwagę, że projekt nie zawiera przepisów, które zapewniałyby spełnienie tego warunku. Należy dodatkowo wskazać, że w odniesieniu do tego kryterium art. 12 ust. 5 dyrektywy przewiduje, iż do celów ustalenia przedmiotowej proporcji działalności, uwzględnia się średni całkowity obrót - lub odpowiednią alternatywną miarę opartą na działalności, taką jak koszty poniesione przez odnośną osobę prawną lub instytucję zamawiającą - w odniesieniu do usług, dostaw i robót budowlanych za trzy lata poprzedzające udzielenie zamówienia. Jeżeli jednak, ze względu na datę utworzenia odnośnej osoby prawnej lub instytucji zamawiającej, lub rozpoczęcia przez nie działalności, lub ze względu na reorganizację ich działalności, dane dotyczące obrotu - lub alternatywna miara oparta na działalności, taka jak koszty - za poprzednie trzy lata są niedostępne lub nieprzydatne, wystarczające jest wykazanie, że miara działalności jest wiarygodna, szczególnie za pomocą prognoz handlowych.

Odnosząc się do trzeciego kryterium, określonego w art. 12 ust. 1 lit. c, wystarczy wskazać, że w przypadku opiniowanego projektu nie przewiduje się otwarcia na kapitał prywatny.

Podsumowując, z trzech warunków wskazanych w art. 12 ust. 1 dyrektywy, bez wątpienia spełniony jest trzeci, W zakresie, w jakim warunek drugi uzna się za element sytuacji faktycznej, nie podlega on ocenie w niniejszej opinii. Niemniej należy zwrócić uwagę, że projekt nie zawiera przepisów, które zapewniałyby spełnienie tego warunku. W odniesieniu natomiast do kryterium kontroli, bezpodstawne byłoby wykluczenie a priori możliwości spełnienia go w ocenianym przypadku. Istnieją natomiast podstawy uznania Spółki za wykonawcę ob-

${ }^{21}$ Por. wyrok TSUE z 10 września 2009 r. w sprawie C-573/07, Sea, pkt 71. 
jętego wyłączeniem z art. 12 dyrektywy 2014/24 jako transakcji wewnętrznej. Powyższy wniosek odnosi się jednak tylko do zamówień, w przypadku których emitentem dokumentu jest organ państwa. To on (a dokładniej: Skarb Państwa) byłby bowiem instytucją kontrolującą w rozumieniu art. 12 dyrektywy.

Dla uzupełnienia należy podkreślić, że uznanie zamówienia za transakcję wewnętrzną pociąga za sobą daleko idące konsekwencje w postaci wyłączenia w stosunku do tej transakcji wielu reguł rynku wewnętrznego UE. Co prawda, instytucje zamawiające muszą przestrzegać m.in. art. 49 i 56 TFUE oraz zasad równości traktowania i niedyskryminacji ze względu na przynależność państwową, jak również wynikającego z nich obowiązku przejrzystości, nawet w przypadku transakcji nieobjętych dyrektywą (np. z uwagi na zbyt niską szacowaną wartość zamówienia). Stosowanie tych reguł jest jednak wyłączone w przypadku, gdy kontrola sprawowana przez instytucję zamawiającą jest analogiczna do tej, jaką sprawuje ona nad własnymi służbami, a podmiot ten wykonuje zasadniczą część swej działalności wspólnie z organem władzy lub władzami, w których dyspozycji pozostaje ${ }^{22}$.

\section{Znaczenie wyroku w sprawie C-187/16 dla opiniowanego projektu}

W uzasadnieniu projektu wskazuje się, że: [z]lecenie produkcji wymienionych dokumentów poza systemem zamówień publicznych umożliwi skuteczne sprawowanie przez państwo kontroli nad ich produkcja, przejawiające się między innymi $w$ wyborze podmiotu spełniajacego warunki bezpieczeństwa produkcji, określone $w$ ustawie. Ponieważ powierzenie takiemu podmiotowi produkcji dokumentów będzie stanowiło rękojmię, że nie dojdzie do osłabienia bezpieczeństwa wewnętrznego i zewnętrznego państwa, włączenie wymienionych dokumentów do kategorii pierwszej dokumentów publicznych jest działaniem adekwatnym (s. 8 uzasadnienia projektu). Ponadto: powierzenie, co do zasady, produkcji najistotniejszych dokumentów publicznych podmiotowi kontrolowanemu przez państwo daje gwarancję wpływu państwa na poziom bezpieczeństwa tych dokumentów. Regulacja ta wraz z wyłączeniem dokumentów pierwszej kategorii spod stosowania przepisów o zamówieniach publicznych (art. 64 projektu) umożliwi ochrone podstawowych interesów bezpieczeństwa państwa i bezpieczeństwa publicznego. Powierzenie produkcji dokumentów identyfikacyjnych Spółce ma również służyć ochronie danych osobowych oraz bezpieczeństwu transakcji, przy których wykorzystywane sa zabezpieczone dokumenty (s. 11-12 uzasadnienia projektu). Ponadto projektodawca wskazuje, że: proces wywarzania dokumentów publicznych oraz druków, o których

22 Wyrok TSUE z 10 września 2009 r. w sprawie C-573/07, Sea, pkt 39-40. Por. wyrok TSUE z 8 grudnia 2016 r. w sprawie C-553/15, Undis Servizi, ECLI:EU:C:2016:935, pkt 24. 
mowa $w$ zmienianym art. 4 pkt 5 c u.p.z.p., wymaga stosowania szczególnych procedur bezpieczeństwa, nie jest [więc - dopisek M.J.] możliwe udzielanie w odniesieniu do nich zamówień publicznych w oparciu o przepisy ustawy, w tym w oparciu o przepisy rozdziału 4 a u.p.z.p., co uzasadnia wyłaczenie ich wytwarzania spod obowiązku stosowania u.p.z.p. i jest zgodne z art. 15 ust. 2 dyrektywy 2014/24/UE, w tym $z$ art. 346 ust. 1 lit. a TFUE (s. 21 uzasadnienia projektu).

Oceniając uzasadnienie projektu w świetle wyroku w sprawie C-187/16, należy przede wszystkim zaznaczyć, że istnieje związek między bezpieczeństwem a prawidłowym zabezpieczeniem dokumentów. Wielokrotnie zwracała na to uwagę również Komisja Europejska, zdaniem której: [p]rzestępstwa przeciwko wiarygodności dokumentów stworzyły możliwości działania dla terrorystów i przestępczości zorganizowanej. Są również powiązane z handlem ludźmi (...) W związku z powyższym UE, a w szczególności państwa członkowskie, musza zwiększyć wysiłki na rzecz poprawy bezpieczeństwa dokumentów podróży wydawanych obywatelom UE oraz państw trzecich. Bezpieczeństwo dokumentów podróży jest ważnym czynnikiem mającym znaczenie dla lepszej ochrony granic i zarządzania migracjami oraz torowania drogi ku rzeczywistej i skutecznej unii bezpieczeń$s t w a^{23}$. Co istotne dla opiniowanego projektu, KE w tym samym dokumencie podkreśla również, że to: państwa członkowskie ponosza petna odpowiedzialność za dokumenty umożliwiające ustalenie tożsamości oraz za faktyczna produkcje i wydawanie dokumentów podróży. Komisja oraz państwa członkowskie powinny dopilnować, aby w przypadku wszystkich środków, o których mowa w przedmiotowym planie działania, zagwarantować prawa podstawowe, w szczególności prawo do ochrony danych osobowych. Związek między prawidłowym zabezpieczeniem dokumentów a ochroną bezpieczeństwa nie budził również wątpliwości TSUE.

Trybunał Sprawiedliwości UE potwierdził przedstawiony przez Austrię argument, że to do państw członkowskich należy określenie ich podstawowych interesów bezpieczeństwa. W rozpatrywanym przypadku do austriackich organów należy więc określenie środków bezpieczeństwa koniecznych dla ochrony bezpieczeństwa publicznego tego państwa członkowskiego w procesie drukowania dokumentów tożsamości i innych dokumentów, takich jak dokumenty omawiane w sprawie C-187/16. Należy też zwrócić uwagę, że TSUE w pewnym stopniu zaakceptował (bezpośrednio lub pośrednio) stanowisko strony austriackiej. Przede wszystkim nie zakwestionował podstawowych interesów bezpieczeństwa, które Austria uznała za wymagające ochrony, ani też gwarancji związanych z ochroną tych interesów (tj. konieczności scentralizowanej realizacji zamówień, konieczności zapewnienia skutecznych kontroli administracyjnych oraz konieczność zapewnienia gwarancji dostaw, pkt 80-87 wyroku). Zajął natomiast przeciwne stanowisko co do ciężaru dowodu w odniesieniu do niezbędności wprowadzonych odstępstw. Austria podała argument, zgodnie z którym dyrek-

$23 \operatorname{COM}(2016) 790$ final. Zob. też np. COM(2016) 602 final, COM(2018) 212 final. 
tywy nie przewidują, aby to państwo członkowskie musiało wykazać, że przetarg jest całkowicie niemożliwy (pkt 66 wyroku). Według TSUE natomiast to na państwie członkowskim spoczywa obowiązek wykazania, że stosowanie tych uregulowań jest konieczne dla ochrony jego podstawowych interesów bezpieczeństwa (pkt 78 wyroku). W analizowanej sprawie Trybunał odrzucił argumentację Austrii w tym zakresie, nie znajdując w jej wywodzie wystarczająco przekonujących argumentów. Nie oznacza to, że wyłączenie wytwarzania określonych kategorii dokumentów spod reżimu dyrektywy na podstawie jej art. 15 ust. 2 i 3 nie jest możliwe. Jego dopuszczalność jest jednak uwarunkowana przedstawieniem przez państwo argumentów, które zostaną zaakceptowane przez TSUE. Wydaje się jednak, że w świetle wymagającego podejścia Trybunału, zaprezentowanego w omawianym wyroku, możliwość ta pozostaje bardziej teoretyczna niż praktyczna. Należy też zwrócić uwagę, że analizowany wyrok został wydany przez Trybunał orzekający w składzie Wielkiej Izby. Pozwala to przypuszczać, że stanowisko zajęte przez TSUE w tym wypadku określi kierunek orzecznictwa w kolejnych tego typu sprawach. Wymaga podkreślenia również ta okoliczność, że stanowisko TSUE odnosi się nie tylko do sytuacji, w której państwo członkowskie zamierzałoby oprzeć się na art. 15 dyrektywy 2014/24, ale również na art. 346 ust. 1 lit. a TFUE (pkt 72, 78-79, 96 wyroku) ${ }^{24}$.

Oceniając z tej perspektywy uzasadnienie projektu, należy uznać, że jest ono niewystarczające. Projektodawca powinien zapoznać się z argumentami podnoszonymi w omawianej sprawie przez Austrię oraz z ich krytyką ze strony Trybunału, a następnie ocenić, czy w opiniowanym projekcie możliwe jest przedstawienie bardziej przekonujących argumentów. W przeciwnym razie odwołanie się do art. 15 ust. 2 i 3 dyrektywy 2014/24 wydaje się skazane na porażkę. Aktualność zachowuje tu stanowisko wyrażone w przywołanej wcześniej opinii BAS z 26 lutego 2018 r. $^{25}$, gdzie wskazuje się, że art. 15 ust. 2 dyrektywy 2014/24 wyłącza jej zastosowanie jedynie w stopniu, w jakim ochrona podstawowych interesów danego państwa członkowskiego w zakresie bezpieczeństwa nie może zostać zagwarantowana przez mniej inwazyjne środki, na przykład przez nałożenie wymogów mających na celu ochronę poufnego charakteru informacji udostępnianych przez instytucję zamawiającą w trakcie trwania postępowania o udzielenie zamówienia zgodnie $\mathrm{z}$ tą dyrektywą. Tymczasem uzasadnienie projektu w zasadzie nie odnosi się do tego wymogu. Nie wyjaśnia ono, jakie „mniej inwazyjne” rozwiązania alternatywne były brane pod uwagę i dlaczego projektodawca uznał je za niecelowe (np. z uwagi na niedostateczną skuteczność, nadmierny koszt,

24 Treść art. 346 ust. 1 lit. b TFUE nie ma zastosowania w przypadku opiniowanego projektu, ponieważ przepis ten umożliwia podjęcie działań w celu ochrony podstawowych interesów bezpieczeństwa, jednak tylko odnoszących się do produkcji lub handlu bronią, amunicją lub materiałami wojennymi.

25 P. Bachmat, M. Jaśkowski, Ocena rządowego projektu ustawy, op. cit. 
nadmierny stopień skomplikowania). W szczególności projektodawca nie odniósł się do wyrażonej wprost przez art. 15 ust. 2 dyrektywy 2014/24 możliwości polegającej na nałożeniu wymogów mających na celu ochronę poufnego charakteru informacji udostępnianych przez instytucję zamawiającą.

W cytowanej opinii BAS wskazano też, że spójność projektowanych rozwiązań może zostać zakwestionowana w związku z treścią art. 17 ust. 6 projektu, który przewiduje możliwość wytworzenia dokumentu publicznego, o którym mowa w art. 5 ust. 2 projektu, przez inny podmiot, o którym mówi art. 18 projektu (spełniający określone w projekcie wymogi), gdyby wytworzenie go przez Spółkę według warunków określonych przez emitenta okazało się niemożliwe. Zgodnie z uzasadnieniem: [s]ytuacja, w której Spółka może nie być $w$ stanie wytworzyć blankietów dokumentów publicznych pierwszej kategorii zgodnie z warunkami określonymi przez emitenta dokumentu publicznego (lub Krajową Radę Notarialna w przypadku zamawiania dokumentów notarialnych), może zaistnieć np. w przypadku braku możliwości realizacji przez Spółkę zamówienia na wytworzenie dokumentu publicznego w określonym przez emitenta terminie, liczbie lub cenie (s. 11 uzasadnienia projektu). Niespójność polega na tym, że projektodawca z jednej strony uważa wytwarzanie dokumentów przez Spółkę za konieczne z uwagi na ochronę podstawowych interesów państwa w zakresie bezpieczeństwa, z drugiej przewiduje możliwość odstąpienia od tego rzekomo koniecznego ograniczenia, co więcej, z tak stosunkowo nieistotnego w tym kontekście powodu jak choćby cena wytworzenia dokumentu. Wobec powyższego BAS przedstawił wątpliwość, czy wszystkie dokumenty nie mogłyby być wytwarzane przez inne podmioty, o których mowa w art. 18 projektu. Należy zauważyć, że podobne rozwiązanie występowało w przepisach austriackich stanowiących przedmiot postępowania w sprawie C-187/16. Zostało to podniesione w trakcie postępowania sądowego przez Komisję Europejską (pkt 54 wyroku), jednak TSUE nie odniósł się do tej kwestii. Nie należy jednak wyciągać na tej podstawie wniosku, jakoby rozwiązanie zostało w dorozumiany sposób uznane za dopuszczalne przez Trybunał. Wydaje się raczej, że stwierdziwszy niezgodność przepisów austriackich z prawem Unii z powodów wskazanych w podrozdziale zatytułowanym Wyrok niniejszej opinii, TSUE nie widział potrzeby rozpatrywania wszystkich okoliczności, które mogłyby potwierdzić te niezgodność.

Aktualność zachowują również pozostałe wątpliwości wskazane w przytoczonej opinii BAS.

\section{Wnioski}

Mimo zmiany stanu prawnego, polegającej na zastąpieniu dyrektywy 2004/18 dyrektywą 2014/24, wyrok Trybunału Sprawiedliwości UE w sprawie C-187/16 zachowuje aktualność również w odniesieniu do obecnego stanu prawnego. 
Stan prawny stanowiący przedmiot oceny w sprawie C-187/16 charakteryzuje się znacznym podobieństwem do rozwiązań zawartych w ocenianym projekcie. Istotną różnicą jest jednak okoliczność, że Österreichische Staatsdruckerei jest spółka prywatną, natomiast Spółka, o której mówi art. 17 projektu, ma być jednoosobową spółką Skarbu Państwa. W ocenie BAS nie jest więc wykluczone objęcie wytwarzania określonych dokumentów wyłączeniem przewidzianym w art. 12 ust. 1 dyrektywy 2014/24, zależy to jednak od spełnienia dodatkowych warunków.

W przypadku, w którym Spółka, o której mówi art. 17 projektu, nie zostałaby uznana za podmiot objęty wyłączeniem przewidzianym w art. 12 ust. 1 dyrektywy 2014/24, powołanie się na konieczność ochrony podstawowych interesów bezpieczeństwa państwa w rozumieniu art. 15 ust. 2 i 3 dyrektywy 2014/24 oraz art. 346 ust. 1 lit. a TFUE wymagałoby uzupełnienia argumentacji projektu w sposób uwzględniający stanowisko zajęte przez Trybunał Sprawiedliwości UE w wyroku C-187/16.

\section{Bibliografia}

Bachmat P., Jaśkowski M., Ocena rządowego projektu ustawy o dokumentach publicznych (druk sejmowy nr 2153), „Zeszyty Prawnicze BAS” 2018, nr 1(57).

Sánchez Graells A., Public Procurement and the EU Competition Rules, Oxford 2011, https://doi.org/10.5040/9781472560872. 